\title{
Carnobacterium pleistocenium sp. nov., a novel psychrotolerant, facultative anaerobe isolated from permafrost of the Fox Tunnel in Alaska
}

Correspondence
Elena V. Pikuta
elena.pikuta@msfc.nasa.gov

\author{
Elena V. Pikuta, ${ }^{1}$ Damien Marsic, ${ }^{2}$ Asim Bej, ${ }^{3}$ Jane Tang, ${ }^{4}$ Paul Krader ${ }^{4}$ \\ and Richard B. Hoover ${ }^{1}$ \\ ${ }^{1}$ NASA/NSSTC, XD12, 320 Sparkman Drive, Room 4247, Huntsville, AL 35805, USA \\ ${ }^{2}$ Laboratory for Structural Biology, The University of Alabama in Huntsville, MSB, Huntsville, \\ AL 35899, USA \\ ${ }^{3}$ Department of Biology, University of Alabama at Birmingham, Birmingham, AL 35294, USA \\ ${ }^{4}$ American Type Culture Collection, 10801 University Blvd, Manassas, VA 20110, USA
}

The genus Carnobacterium presently includes eight species: Carnobacterium divergens, C. gallinarum, C. mobile, C. inhibens, C. funditum, C. alterfunditum, C. viridans and C. maltaromaticum. All of these species are capable of growing at low temperatures and most of them were isolated from refrigerated food, except for the species $C$. funditum and $C$. alterfunditum, which were isolated from anoxic waters in Ace Lake, Antarctica (Franzmann et al., 1991). Some of these species are known as fish pathogens (Hiu et al., 1984). The species Carnobacterium piscicola (Collins et al., 1987) and Lactobacillus maltaromicus (Miller et al., 1974) were recently identified as synonyms and the two species were transferred to C. maltaromaticum (Mora et al., 2003). All species of the genus are facultative anaerobes and are capable of reducing resazurin in aerobic media during growth. In nature, they may act as primary agents responsible for the reduction of oxygen levels in

Published online ahead of print on 24 September 2004 as DOI 10.1099/ijs.0.63384-0.

The GenBank/EMBL/DDBJ accession number for the 16S rRNA gene sequence of strain $\mathrm{FTR}^{\top}{ }^{\top}$ is $\mathrm{AF} 450136$. ecosystems and for the creation of advantageous conditions for the development of obligately anaerobic micro-organisms (Franzmann et al., 1991).

In this article we describe a novel psychrotolerant, facultatively anaerobic bacterium isolated from the permafrost tunnel in Fox, Alaska. In previous work, we described in detail the isolation of the novel bacterium and characterized the ecosystem in which it was found (Hoover et al., 2002; Pikuta \& Hoover, 2003). Since the geological age of the sample is dated as the Pleistocene epoch, we suggest the name Carnobacterium pleistocenium sp. nov. for the novel species.

Strain FTR $1^{\mathrm{T}}$ was isolated from an ice core sample collected from the lower level of a frozen lenticular ice lens (Fig. 1) associated with a Pleistocene thermokarst pond (age $\sim 32000$ years) in the CRREL (Cold Regions Research and Engineering Laboratory) Fox Permafrost Tunnel, which is approximately $15 \mathrm{~km}$ north of Fairbanks, Alaska (Hoover \& Gilichinsky, 2001).

The sample was kept in a frozen state during transportation 


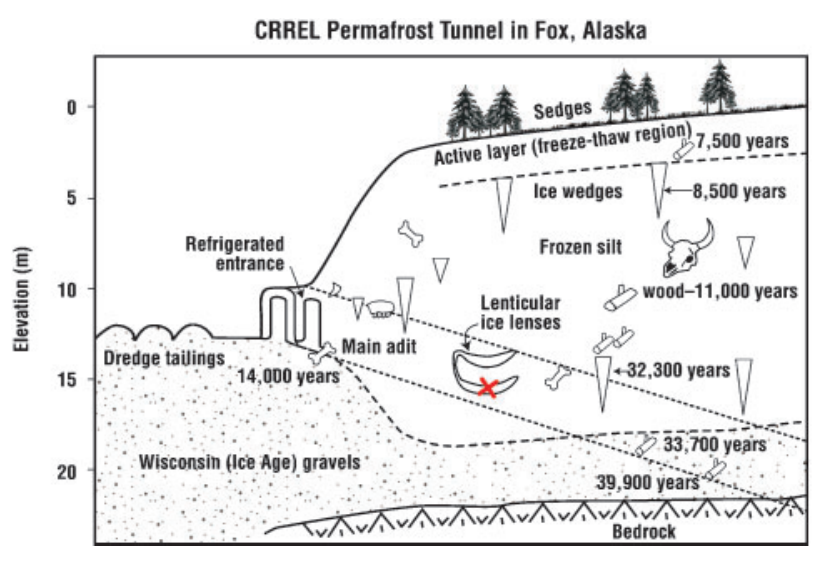

Fig. 1. Schematic image of the geological profile of the CRREL Permafrost Tunnel in Fox, Alaska (modified with permission from Davis, 2004). The red cross designates the sampling site.

to the Astrobiology Laboratory at NSSTC and stored at $-20^{\circ} \mathrm{C}$ in the laboratory freezer. The permafrost material was melted anaerobically at $2{ }^{\circ} \mathrm{C}$, homogenized and injected into Hungate tubes with an anaerobic medium and was incubated for 2 months at $2{ }^{\circ} \mathrm{C}$. Enrichment cultures were obtained by using anaerobic technique with a medium containing $\left(\mathrm{g} \mathrm{l}^{-1}\right)$ : $\mathrm{NaCl}, 10 \cdot 0 ; \mathrm{KCl}, 0 \cdot 3 ; \mathrm{KH}_{2} \mathrm{PO}_{4}, 0 \cdot 3$; $\mathrm{MgSO}_{4} .7 \mathrm{H}_{2} \mathrm{O}, 0 \cdot 1 ; \mathrm{NH}_{4} \mathrm{Cl}, 1 \cdot 0 ; \mathrm{CaSO}_{4} .7 \mathrm{H}_{2} \mathrm{O}, 0 \cdot 0125$; $\mathrm{NaHCO}_{3}, 0 \cdot 4 ; \mathrm{Na}_{2} \mathrm{~S} .9 \mathrm{H}_{2} \mathrm{O}, 0 \cdot 4$; resazurin, $0 \cdot 0001$; yeast extract, $0 \cdot 2$; peptone, $3 \cdot 0 ; 2 \mathrm{ml}$ vitamin solution (Wolin et al., 1963); and $1 \mathrm{ml}$ trace mineral solution (Whitman et al., 1982). The final $\mathrm{pH}$ was $7 \cdot 14-7 \cdot 2$. High-purity nitrogen was used as the gas phase. A pure culture was obtained by the dilution method in Hungate tubes and supported on medium with a modified $\mathrm{NaCl}$ concentration of $0.5 \%(\mathrm{w} / \mathrm{v})$. The ninth dilution of the morphologically monotypic culture was chosen for growth of colonies on agar medium. Isolation of colonies was performed by the roll-tube method on $3 \%(\mathrm{w} / \mathrm{v})$ agar medium. After 10-14 days incubation at $2{ }^{\circ} \mathrm{C}$, colonies of strain FTR $1^{\mathrm{T}}$ were white to cream in colour and round, convex lens-shaped (in deep agar) with a diameter of around 1-2 $\mathrm{mm}$. Colonies grown on the agar surface were conical in shape and the centre had a denser consistency and darker colour than the perimeter. The surface of colonies was granulated and rough with thinner, irregular, torn edges.

Pure cultures in all experiments were incubated at $4-22{ }^{\circ} \mathrm{C}$. The purity of the culture was checked by microscopic control during this study.

The morphology of the novel isolate was examined under a phase-contrast microscope (Fisher Micromaster) and a Hitachi S-4000 field-emission scanning electron microscope was used to examine the ultramicrostructure of the cell surface. An epifluorescence microscope Leitz Diaplan was used with DAPI and BacLite live/dead cell stains. Cells of
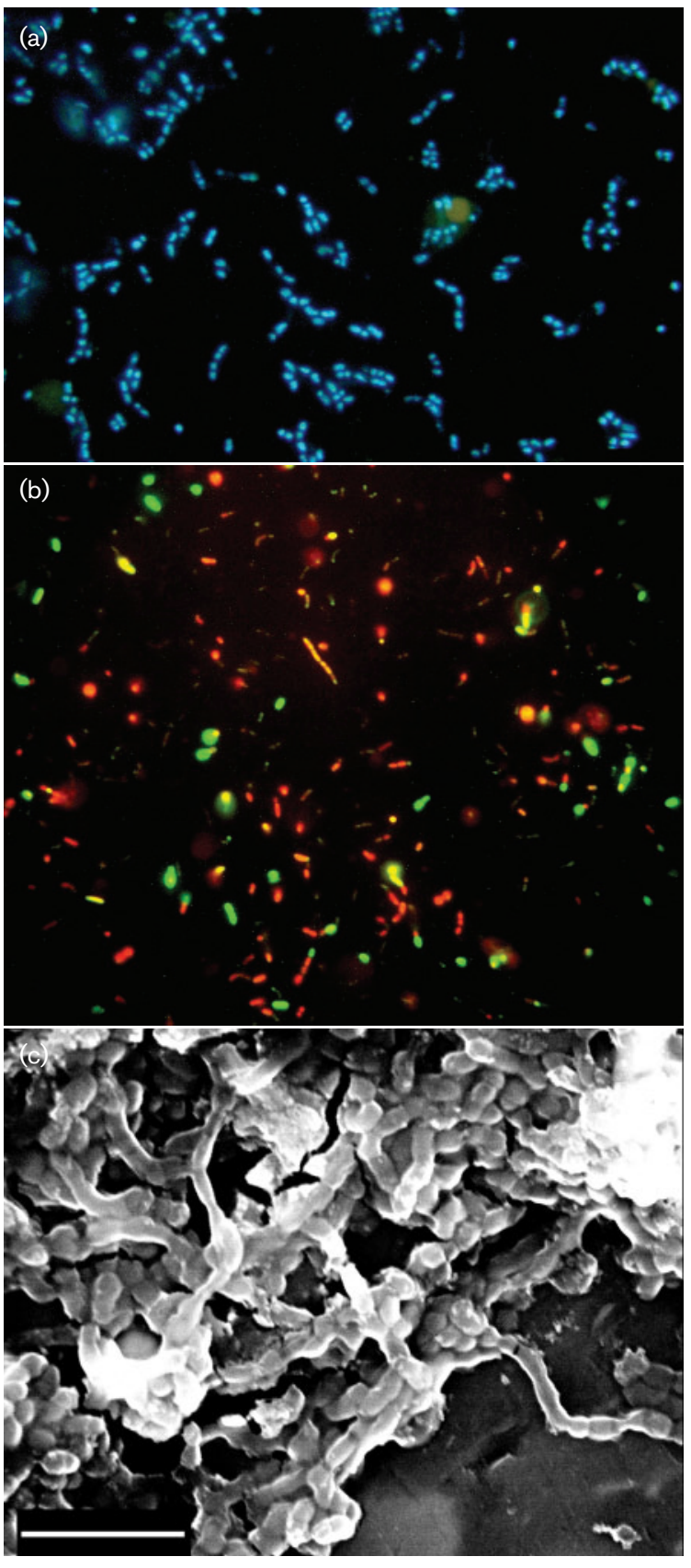

Fig. 2. Images of strain $F T R 1^{\top}$ : (a) DAPI-stained cells under a Leitz Diaplan epifluorescence microscope; (b) BacLite live/dead stain; (c) Hitachi S-4000 field emission scanning electron microscope (bar $5 \mu \mathrm{m}$ ).

strain FTR $1^{\mathrm{T}}$ were small, short rods with rounded ends and were $0 \cdot 7-0 \cdot 8 \mu \mathrm{m}$ wide and $1 \cdot 0-1 \cdot 5 \mu \mathrm{m}$ long (Fig. 2). Cells were motile and stained Gram-positive. Spores were never observed. Cells occurred singly, in pairs or in short, irregular curved chains.

Growth of the culture was determined by direct cell counting under a phase-contrast microscope or by measuring the 
$\mathrm{OD}$ at $595 \mathrm{~nm}$ (Genesis 5; Spectronic Instruments). Catalase activity was determined by the reaction with hydrogen peroxide (Gerhardt et al., 1981). All substrates were added to the medium, containing $0 \cdot 1 \mathrm{~g}$ yeast extract $\mathrm{l}^{-1}$, at concentrations of $3 \mathrm{~g} \mathrm{l}^{-1}$. End products of peptone fermentation in the liquid phase were determined by HPLC. Separation was done on an Aminex HPX-87H (Bio-Rad) column with $5 \mathrm{mM} \mathrm{H}_{2} \mathrm{SO}_{4}$ as the mobile phase. Gases were measured using a gas chromatograph 3700 (Varian) equipped with a Porapak Q column and TCD detector. Nitrogen was used as the gas carrier.

The novel isolate was a facultative anaerobe and grew well under aerobic and anaerobic conditions. During growth under aerobic conditions resazurin was reduced (i.e. became colourless). Strain FTR $1^{\mathrm{T}}$ had a negative catalase reaction. The novel isolate could grow without $\mathrm{NaCl}$ with a longer lag phase (three passages on a medium in which all sodium salts were replaced by potassium salts and chloride salts were replaced by sulfates). The $\mathrm{NaCl}$ range for growth was $0-5 \%(\mathrm{w} / \mathrm{v})$, with optimum growth at $0 \cdot 5 \%(\mathrm{w} / \mathrm{v})$. At $7 \%$ $\mathrm{NaCl}$, growth was absent. Strain FTR $1^{\mathrm{T}}$ grew in $\mathrm{pH}$ range $6 \cdot 5-9 \cdot 5$ and had optimum growth at $\mathrm{pH} 7 \cdot 3-7 \cdot 5$. The temperature range for growth of the novel isolate was $0-28{ }^{\circ} \mathrm{C}$ with optimal growth at $24^{\circ} \mathrm{C}$.

Strain FTR $1{ }^{\mathrm{T}}$ had a chemoorganoheterotrophic metabolism and was capable of growth on the following substrates: Dglucose, D-fructose, D-mannose, D-maltose, sucrose, lactose, starch, D-mannitol, peptone, Bacto tryptone, Casamino acids and yeast extract. The best growth was observed on D-trehalose and the weakest growth was on D-arabinose. No growth was observed with formate, acetate, lactate, pyruvate, propionate, butyrate, citrate, ethanol, methanol, glycerol, acetone, betaine, trimethylamine or triethylamine.

Metabolic end products of culture on glucose were acetate $(1.2 \mathrm{mM})$ and ethanol $(6.3 \mathrm{mM})$ in the liquid phase and traces of $\mathrm{CO}_{2}$ in the gas phase.

Concentrations of antibiotics used for testing were $250 \mu \mathrm{g}$ $\mathrm{ml}^{-1}$ for ampicillin, kanamycin, gentamicin, tetracycline and rifampicin and $125 \mu \mathrm{g}$ chloramphenicol $\mathrm{ml}^{-1}$. Strain FTR $1^{\mathrm{T}}$ was sensitive to all antibiotics tested.

For extraction of fatty acid methyl esters, the culture was incubated for 4 days at $22{ }^{\circ} \mathrm{C}$ on the medium described above. The extraction procedure and instruments were described previously (Pikuta et al., 2003). The major fatty acids for strain $\mathrm{FTR}_{1}^{\mathrm{T}}$ were $\mathrm{C}_{14: 0}, \mathrm{C}_{16: 1}$ cis $7, \mathrm{C}_{16: 0}, \mathrm{C}_{18: 1}$ cis 9 and $\mathrm{C}_{18: 0}$ (Table 1).

Genomic DNA was isolated through phenol/chloroform extraction of sonicated biomass followed by ethanol precipitation (Sambrook et al., 1989). The 16S rRNA gene of strain $\mathrm{FTR} 1^{\mathrm{T}}$ was amplified and sequenced as described previously (Hoover et al., 2003), except for a slight change in the thermal cycling profile (time of initial denaturation at $95^{\circ} \mathrm{C}$ was $2 \mathrm{~min}$ ) and the use of a modified set of $16 \mathrm{~S}$
Table 1. Fatty acid compositions of C. pleistocenium sp. nov. FTR $1^{\top}$ and C. alterfunditum $\mathrm{pf} 4^{\top}$

Values are percentages $(\mathrm{w} / \mathrm{w})$ of total fatty acids. Summed feature 4 represents unresolved 15:2 FAME and/or 15:1cis7. Summed feature 10 represents unresolved 18:1cis $11 /$ trans $9 /$ trans6. Data for C. alterfunditum were taken from Franzmann et al. (1991). DMA, Dimethylacetate; FAME, fatty acid methyl ester.

\begin{tabular}{|lrr|}
\hline Compound & FTR1 $^{\mathbf{T}}$ & $\mathbf{p f 4}^{\mathbf{T}}$ \\
\hline $12: 0$ FAME & $1 \cdot 27$ & $0 \cdot 00$ \\
$14: 0$ FAME & $7 \cdot 19$ & $7 \cdot 10$ \\
Summed feature 4 & $0 \cdot 00$ & $0 \cdot 80$ \\
$16: 1$ cis7 FAME & $20 \cdot 73$ & $7 \cdot 50$ \\
$16: 0$ FAME & $37 \cdot 07$ & $40 \cdot 90$ \\
$16: 0$ DMA & $0 \cdot 00$ & $0 \cdot 80$ \\
$18: 2$ cis9,12 FAME & $1 \cdot 76$ & $0 \cdot 00$ \\
$18: 1$ cis9 FAME & $24 \cdot 32$ & $7 \cdot 90$ \\
Summed feature 10 & $1 \cdot 56$ & $12 \cdot 1$ \\
$18: 0$ FAME & $4 \cdot 83$ & $5 \cdot 10$ \\
20:1 cis11 FAME & $1 \cdot 28$ & $0 \cdot 90$ \\
\hline
\end{tabular}

rRNA-specific sequencing primers: 5'-GCCAGCAGCCGCGGTAATAC (Escherichia coli positions 516-535), 5' -TCGTCAGCTCGTGTCGTGAG (1061-1080), 5'-GGGTTGCGCTCGTTGCGGG (1113-1095) and 5'-GCGCTCGCTTTACGCCCAAT (581-562).

The consensus sequence was aligned with eight closely related sequences using CLUSTAL W (Thompson et al., 1994). Pairwise distances were computed with MEGA version 2.1 (Kumar et al., 2001) using the Jukes-Cantor model (Jukes \& Cantor, 1969). An unrooted phylogenetic tree was constructed with the same program using the neighbourjoining method (Saitou \& Nei, 1987).

A sequence covering 1486 nucleotides of the 16S rRNA gene was obtained, corresponding to positions 28-1492 of the E. coli $16 \mathrm{~S}$ rRNA sequence. No difference was observed between the sequences of the three selected clones. The $\mathrm{G}+\mathrm{C}$ content of this sequence was $53.5 \mathrm{~mol} \%$. The sequence was compared with all sequences presently available in the GenBank database and appeared to be highly similar to sequences from Carnobacterium species. A phylogenetic dendrogram was constructed based on 1379 common nucleotides sites, and the dendrogram shows the position of strain $\mathrm{FTR} 1^{\mathrm{T}}$ among all currently known species of the genus Carnobacterium (Fig. 3). According to the pairwise distance table (not shown), based on the same 1379 common nucleotide sites, strain FTR $1^{\mathrm{T}}$ appears to belong to a cluster including C. alterfunditum, C. inhibens and C. viridans, with $99 \cdot 78,98 \cdot 54$ and $98 \cdot 83 \%$ similarity, respectively. Since the similarity of the novel isolate was determined to be highest to C. alterfunditum $\mathrm{pf} 4^{\mathrm{T}}$, it was suggested that an additional genetic comparison be performed for the two strains.

Melting temperatures $\left(T_{\mathrm{m}}\right)$ of total genomic DNA from 


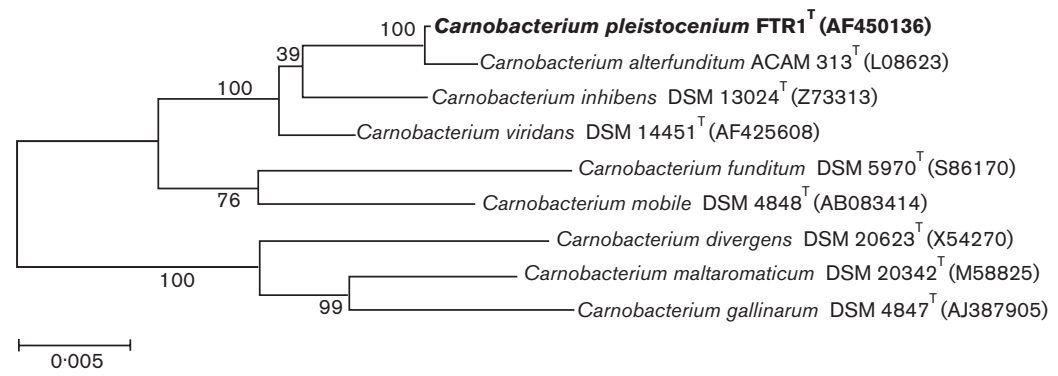

Fig. 3. Unrooted phylogenetic tree showing the position of strain $\mathrm{FTR}^{\top}$ among other species of the genus Carnobacterium. Numbers at nodes are bootstrap percentages (1000 replicates). Sequence accession numbers are shown in parentheses (note that accession number L08623 for C. alterfunditum erroneously gives the strain as ACAM 311, a strain of Psychrobacter urativorans; J. P. Bowman, personal communication). Bar, 5 substitutions per 1000 nucleotides.

strain $\mathrm{FTR} 1^{\mathrm{T}}$ and C. alterfunditum $\mathrm{pf} 4^{\mathrm{T}}$ were determined by procedures previously described (De Ley et al., 1970; Gillis et al., 1970). Purified genomic DNA $(200 \mu \mathrm{g})$ from strain FTR $1^{\mathrm{T}}$ and C. alterfunditum $\mathrm{pf} 4^{\mathrm{T}}$ was sonicated to generate DNA fragments of 500-700 bp. Any residual RNA and single-stranded DNA was removed by treatment with RNase A and S1 nuclease, respectively (Ausubel et al., 1987). The concentration and purity of the DNA were determined from the $A_{260}$ and the $A_{260} / A_{280}$ ratio using a Shimadzu UV-160 spectrophotometer. DNA $(80 \mu \mathrm{g})$ from each of these micro-organisms was then denatured in $1 \times$ SSC buffer $(\mathrm{pH} \mathrm{7 \cdot 0)}$ by increasing the temperature of the sample from 26 to $100{ }^{\circ} \mathrm{C}$ (at a rate of $1^{\circ} \mathrm{C} \mathrm{min}^{-1}$ ) and the $A_{260}$ was recorded. The experiment was conducted in triplicate. The $T_{\mathrm{m}}$ was determined by calculating the temperature at which the hyperchromicity reached half of the value obtained after complete melting. The $T_{\mathrm{m}}$ of the genomic DNA of strain FTR $1{ }^{\mathrm{T}}$ was $62 \pm 2{ }^{\circ} \mathrm{C}($ mean $\pm \mathrm{SD}$, $n=4)$, whereas it was $53 \pm 3^{\circ} \mathrm{C}(n=4)$ for $C$. alterfunditum $\mathrm{pf} 4^{\mathrm{T}}$.

To determine the relatedness of genomic DNA between strain $\mathrm{FTR} 1^{\mathrm{T}}$ and $C$. alterfunditum $\mathrm{pf} 4^{\mathrm{T}}$, DNA-DNA hybridization was performed by DNA reassociation kinetics as described previously (De Ley et al., 1970; Johnson, 1985). Purified, sonicated genomic DNA $(80 \mu \mathrm{g})$ from each strain was added to $4 \times$ SSC buffer ( $\mathrm{pH} 7 \cdot 0$ ) and $25 \%$ deionized formamide. The DNA was denatured by raising the temperature to $100^{\circ} \mathrm{C}$ and cooled to $5^{\circ} \mathrm{C}$ above the respective melting temperatures. The temperature was then rapidly $(1.5 \mathrm{~min})$ lowered to the reassociation temperature and the $A_{270}$ was recorded at $5 \mathrm{~s}$ intervals for a total of $20 \mathrm{~min}$. The initial reassociation kinetics were determined by linear regression analysis. The experiment was conducted in triplicate. The percentage relatedness of the DNA was calculated using the equation described by De Ley et al. (1970). All statistical analyses were performed using Microsoft Excel. DNA-DNA hybridization established $39 \pm 1 \cdot 5 \%$ relatedness (mean $\pm \mathrm{SD}, n=3$ ) between the genomes of strain FTR $1^{\mathrm{T}}$ and $\mathrm{C}$. alterfunditum $\mathrm{pf} 4^{\mathrm{T}}$.

The genome sizes of strain $\mathrm{FTR} 1^{\mathrm{T}}$ and C. alterfunditum $\mathrm{pf} 4^{\mathrm{T}}$ were determined from the DNA reassociation kinetics, following the equation described by Gillis et al. (1970). The genome sizes were $2 \cdot 1 \times 10^{9} \mathrm{Da}$ for strain $\mathrm{FTR}^{\mathrm{T}}$ and $1 \cdot 9 \times 10^{9} \mathrm{Da}$ for C. alterfunditum $\mathrm{pf} 4^{\mathrm{T}}$.

The $\mathrm{G}+\mathrm{C}$ content in genomic DNA of strain FTR1 ${ }^{\mathrm{T}}$ was determined by following the procedure described by Starr \& Mandel (1968) and Franzmann et al. (1991). The total $\mathrm{G}+\mathrm{C}$ content of the purified genomic DNA for strain FTR ${ }^{\mathrm{T}}$ was $42 \pm 1 \cdot 5$ mol\% (mean \pm SD, $n=3$ ) compared with $33-$ $34 \mathrm{~mol} \%$ for C. alterfunditum (Franzmann et al., 1991).

The novel isolate is the first representative of this genus to be found alive in ice entrained in Pleistocene permafrost. Detailed characterization of this ecosystem and the importance of its study to paleomicrobiology, biostratigraphy, geocryology, microbial evolution, conservation of the modern gene pool and the long-term viability of microorganisms in deep anabiosis were described previously (Hoover et al., 2002). Indeed, there is still much less known about the microbiota preserved in Pleistocene permafrost and ice than is known about fossil Pleistocene mammals. In Table 2, distinguishing features of the novel isolate and C. alterfunditum $\mathrm{pf} 4^{\mathrm{T}}$ are shown. Notwithstanding the different sources of isolation for the two strains, a very close phylogeny and physiology is demonstrated, while some metabolic features have significant differences. For example, the sugars that could be used as substrates are different, and lactic acid is absent from the end products of strain FTR $1^{T}$. Also, the composition of fatty acid methyl esters in the novel isolate is different: 16:0 DMA is absent from strain FTR $1^{\mathrm{T}}$, but it represents around $0 \cdot 8 \%$ of the total in C. alterfunditum pf4 ${ }^{\mathrm{T}} ; 12: 0$ FAME and 18:2cis 9,12 FAME are present in strain FTR $1^{\mathrm{T}}$, but they are absent from C. alterfunditum $\mathrm{pf}^{\mathrm{T}}{ }^{\mathrm{T}}$ (Table 1). DNA-DNA hybridization of genomic DNA between strain FTR $1^{\mathrm{T}}$ and C. alterfunditum $\mathrm{pf}^{\mathrm{T}}{ }^{\mathrm{T}}$ exhibited only $39 \%$ relatedness. Also, the melting temperature, the $\mathrm{G}+\mathrm{C}$ content of the genomic DNA and the genome sizes of the two micro-organisms are different (Table 2).

On the basis of phenotypic and genotypic characteristics (Gram-positive cell wall, facultatively anaerobic and fermentative metabolism, psychrotolerant and slightly alkalitolerant physiology, independence from $\mathrm{NaCl}, 16 \mathrm{~S}$ rRNA gene sequence and DNA-DNA hybridization), strain 
Table 2. Comparative characteristics of strain $\mathrm{FTR} 1^{\top}$ and C. alterfunditum $\mathrm{pf} 4^{\top}$

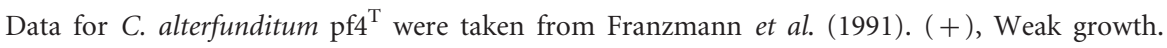

\begin{tabular}{|c|c|c|}
\hline Attribute & FTR1 $^{\mathrm{T}}$ & C. alterfunditum $\mathrm{pf} 4^{\mathrm{T}}$ \\
\hline Temperature range (optimum) $\left({ }^{\circ} \mathrm{C}\right)$ & $0-28(24)$ & $0-28(23)$ \\
\hline $\mathrm{NaCl}$ range (optimum) (\%) & $0 \cdot 1-5 \cdot 0(0 \cdot 5)$ & $(0 \cdot 6)$ \\
\hline pH range (optimum) & $6 \cdot 5-9 \cdot 5(7 \cdot 3-7 \cdot 5)$ & $6 \cdot 0(7 \cdot 0-7 \cdot 4)^{\star}$ \\
\hline \multicolumn{3}{|l|}{ Growth on: } \\
\hline D-Arabinose & $(+)$ & - \\
\hline D-Mannitol & + & - \\
\hline D-Fructose & + & $(+)$ \\
\hline Maltose & + & $(+)$ \\
\hline D-Mannose & + & $(+)$ \\
\hline D-Trehalose & + & - \\
\hline Lactose & + & - \\
\hline D-Ribose & + & - \\
\hline D-Arabinose & + & - \\
\hline Starch & + & - \\
\hline Sucrose & + & $(+)$ \\
\hline \multicolumn{3}{|l|}{ End products: } \\
\hline Lactic acid $\dagger$ & - & + \\
\hline Aesculin hydrolysis & + & - \\
\hline DNA G $+C$ content $(\mathrm{mol} \%)$ & 42 & $33-34$ \\
\hline Genome size $(\mathrm{Da})$ & $2 \cdot 1 \times 10^{9}$ & $1.9 \times 10^{9}$ \\
\hline$T_{\mathrm{m}}\left({ }^{\circ} \mathrm{C}\right)$ & 62 & 53 \\
\hline Ecology & Permafrost deposits in Fox tunnel, Alaska & Ace Lake, Antarctica \\
\hline
\end{tabular}

${ }^{*}$ Minimum $\mathrm{pH}$ of $4 \cdot 9-5 \cdot 4$ achieved on PYG $-2 \% \mathrm{NaCl}$ medium. No maximum $\mathrm{pH}$ for growth was reported. $\dagger$ Both species produce acetic acid and ethanol.

FTR $1^{\mathrm{T}}$ is identified as representing a novel species of the genus Carnobacterium. The name Carnobacterium pleistocenium sp. nov. is suggested for this organism, in accordance with the geological age of the sample from which the type strain was isolated, which dated from the Pleistocene epoch.

\section{Description of Carnobacterium pleistocenium sp. nov.}

Carnobacterium pleistocenium (plei.sto.ce' ni.um. N.L. neut. adj. pleistocenium belonging to the Pleistocene, a geological epoch).

Cells are motile, small rods with rounded ends, $0 \cdot 7-$ $0 \cdot 8 \times 1 \cdot 0-1 \cdot 5 \mu \mathrm{m}$. Gram-positive. Growth occurs between 0 and $28^{\circ} \mathrm{C}$ (optimum $24^{\circ} \mathrm{C}$ ) and at $\mathrm{pH}_{22}{ }^{\circ} \mathrm{C} 6 \cdot 5-9.5$ (optimum $\mathrm{pH} 7 \cdot 3-7 \cdot 5)$. Range of $\mathrm{NaCl}$ for growth is $0-5 \%$ $(\mathrm{w} / \mathrm{v})$; optimum growth at $0 \cdot 5 \%(\mathrm{w} / \mathrm{v}) \mathrm{NaCl}$. Facultative anaerobe. Catalase-negative. Heterotrophic growth occurs with D-glucose, D-fructose, maltose, D-mannitol, Dmannose, D-trehalose, lactose, D-ribose, D-arabinose, sucrose, starch, peptone, Bacto tryptone, Casamino acids and yeast extract. End products of growth are acetate, ethanol and traces of carbon dioxide (in gas phase). Sensitive to ampicillin, kanamycin, gentamicin, tetracycline, rifampicin and chloramphenicol.
The type strain, FTR $1^{\mathrm{T}}\left(=\right.$ ATCC BAA $-754^{\mathrm{T}}=\mathrm{JCM} 12174^{\mathrm{T}}$ $=$ CIP $108033^{\mathrm{T}}$ ), was obtained from a sample of permafrost from Fox Tunnel, Alaska.

\section{Acknowledgements}

We are thankful to Mr Greg Jerman (NASA/Marshall Space Flight Center) for scanning electron microscopy and to Dr V. V. Kevbrin and Professor J. Wiegel (University of Georgia, Athens) for assistance in measuring end products. We are grateful to Professor H. G. Trüper (Bonn University, Germany) and Dr J. Euzéby (École Nationale Vétérinaire, France) for help with nomenclature. We wish to acknowledge the NASA/Johnson Space Center Astrobiology Institute for Biomarkers in Astromaterials for supporting this research.

\section{References}

Ausubel, F. M., Brent, R., Kingston, R. E., Moore, D. D., Sideman, J. G., Smith, J. A. \& Struhl, K. (1987). In Current Protocols in Molecular Biology, pp. 2.10-2.11. New York: Wiley.

Collins, M. D., Farrow, J. A. E., Phillips, B. A., Ferusu, S. \& Jones, D. (1987). Classification of Lactobacillus divergens, Lactobacillus piscicola, and some catalase-negative, asporogenous, rod-shaped bacteria from poultry in a new genus, Carnobacterium. Int J Syst Bacteriol 37, 310-316.

Davis, T. N. (2004). In Alaska Science Nuggets, p. 71. Fairbanks, AK: University of Alaska Press. 
De Ley, J., Cattoir, H. \& Reynaerts, A. (1970). The quantitative measurement of DNA hybridization from renaturation rates. Eur J Biochem 12, 133-142.

Franzmann, P. D., Höpfl, P., Weiss, N. \& Tindall, B. J. (1991). Psychrotrophic, lactic acid-producing bacteria from anoxic waters in Ace Lake, Antarctica; Carnobacterium funditum sp. nov. and Carnobacterium alterfunditum sp. nov. Arch Microbiol 156, 255-262.

Gerhardt, P., Murray, R. G. E., Costilow, R. N., Nester, E. W., Wood, W. A., Krieg, N. R. \& Phillips, G. B. (editors) (1981). Manual of Methods for General Bacteriology. Washington, DC: American Society for Microbiology.

Gillis, M., De Ley, J. \& De Cleene, M. (1970). The determination of molecular weight of bacterial genome DNA from renaturation rates. Eur J Biochem 12, 143-153.

Hiu, S. R., Holt, R. A., Sriranganathan, N., Seidler, R. J. \& Fryer, J. L. (1984). Lactobacillus piscicola, a new species from salmonid fish. Int J Syst Bacteriol 34, 393-400.

Hoover, R. B. \& Gilichinsky, D. (2001). Significance to astrobiology of microorganisms in permafrost and ice. In Permafrost Response on Economic Development, Environmental Security and Natural Resources, NATO Science Series 2, pp. 553-579. Dordrecht: Kluwer Academic Publishers.

Hoover, R. B., Pikuta, E. V., Marsic, D. \& Ng, J. (2002). Anaerobic psychrophiles from Alaska, Antarctica, and Patagonia: implications to possible life on Mars and Europa. In Instruments, Methods, and Missions for Astrobiology IV, Proceedings of SPIE vol. 4495, pp. 313-324. Edited by R. B. Hoover, G. V. Levin, R. R. Paepe \& A. Yu. Rozanov. San Diego: SPIE.

Hoover, R. B., Pikuta, E. V., Bej, A. K., Marsic, D., Whitman, W. B., Tang, J. \& Krader, P. (2003). Spirochaeta americana sp. nov., a new haloalkaliphilic, obligately anaerobic spirochaete isolated from soda Mono Lake in California. Int J Syst Evol Microbiol 53, 815-821.

Johnson, J. L. (1985). DNA reassociation and RNA hybridization of bacterial nucleic acids. Methods Microbiol 18, 33-74.

Jukes, T. H. \& Cantor, C. R. (1969). Evolution of protein molecules. In Mammalian Protein Metabolism, pp. 21-132. Edited by H. M. Munro. New York: Academic Press.
Kumar, S., Tamura, K., Jakobsen, I. B. \& Nei, M. (2001). MEGA2: molecular evolutionary genetics analysis software. Bioinformatics 17 , $1244-1245$

Miller, A., III, Morgan, M. E. \& Libbey, L. M. (1974). Lactobacillus maltaromicus, a new species producing a malty aroma. Int J Syst Bacteriol 24, 346-354.

Mora, D., Scarpellini, M., Franzetti, L., Colombo, S. \& Galli, A. (2003). Reclassification of Lactobacillus maltaromicus (Miller et al. 1974) DSM 20342 ${ }^{\mathrm{T}}$ and DSM 20344 and Carnobacterium piscicola (Collins et al. 1987) DSM $20730^{\mathrm{T}}$ and DSM 20722 as Carnobacterium maltaromaticum comb. nov. Int J Syst Evol Microbiol 53, 675-678.

Pikuta, E. V. \& Hoover, R. B. (2003). Psychrophiles and astrobiology: microbial life of frozen worlds. In Instruments, Methods, and Missions for Astrobiology VI, Proceedings of SPIE vol. 4939, pp. 103-116. Edited by R. B. Hoover, A. Yu. Rozanov \& J. H. Lipps. San Diego: SPIE.

Pikuta, E. V., Hoover, R. B., Bej, A. K., Marsic, D., Detkova, E. N., Whitman, W. B. \& Krader, P. (2003). Tindallia californiensis sp. nov., a new anaerobic, haloalkaliphilic, spore-forming acetogen isolated from soda Mono Lake in California. Extremophiles 7, 327-334.

Saitou, N. \& Nei, M. (1987). The neighbor-joining method: a new method for reconstructing phylogenetic trees. Mol Biol Evol 4, 406-425.

Sambrook, J., Fritch, E. F. \& Maniatis, T. (1989). Molecular Cloning: a Laboratory Manual, 2nd edn. Cold Spring Harbor, NY: Cold Spring Harbor Laboratory.

Starr, M. P. \& Mandel, M. (1968). DNA base composition and taxonomy of phytopathogenic and other enterobacteria. J Gen Microbiol 56, 113-123.

Thompson, J. D., Higgins, D. G. \& Gibson, T. J. (1994). CLUSTAL W: improving the sensitivity of progressive multiple sequence alignment through sequence weighting, position-specific gap penalties and weight matrix choice. Nucleic Acids Res 22, 4673-4680.

Whitman, W. B., Ankwanda, E. \& Wolfe, R. S. (1982). Nutrition and carbon metabolism of Methanococcus voltae. J Bacteriol 149, 852-863. Wolin, E. A., Wolin, M. J. \& Wolfe, R. S. (1963). Formation of methane by bacterial extracts. J Biol Chem 238, 2882-2886. 